\title{
Distribusi dan Utilisasi Lulusan: Suatu Survey
}

\section{Yeni Rustina}

Dosen kKeperawatan Ibu \& Anak FIK-UI, dan Pudek III FIK-UI.

Lulusan merupakan hasil dari proses pendidikan. Utilisasi, distribusi lulusan dan relevansi anatara pekerjaan yang ditekuni dengan pengetahuan yang di dapat selama pendidikan dapat member masukan terhadap sistem pendidikan secara keseluruhan. Penelitian ini bertujuan untuk mengidentifikasi distribusi, utilisasi lulusan dan relevansi antara pekerjaan yang ditekuni dengan pendidikan yang didapat. Metodologi yang digunakan adalah berupa survey dengan menyebarkan angket kepada seluruh lulusan Fakultas Ilmu Keperawatan Universitas Indonesia melalui pos. Pengolahan data dilakukan secara elektrik dengan menggunakan program SSP. Analisa data dibantu uji statistic univariat. Dari 461 angket yang disebar, terkumpul kembali 200 angket (43\%). Hasil yang diperoleh memperlihatkan bahwa lulusan Fakultas Imu Keperawatan Universitas Indonesia tersebar di 18 provinsi di Indonesia dengan tugas utama bidang pendidikan (70\%) dan mayoritas bekerja sebagai dosen (52\%) waktu tunggu untuk mendapatkan pekerjaan pertama lulusan yang berasal dari Program A mayoritas (61\%) kurang dari satu bulan. Dari penelitian ini Fakultas Ilmu Keperawatan mendapatkan beberapa masukan yaitu metoda pembelajaran yang dirasakan paling menunjang keberhasilan proses belajar mengajar adalah praktek klinik (23,5\%); dan diskusi kelompok (19,2\%) dan perlu lebih meningkatkan mata ajar Pendidikan dalam Keperawatan, Manajemen Keperawatan, dan Riset Keperawatan.

Kata kunci: Sistem pendidikan, metoda pembelajaran

Graduate is output of an education process. Graduates utilization, distribution and its relevance between their current position and the gained knowledge during education can provide inputs to the whole education systems. This study was aimed at identifying graduates distribution, utilization and its relevance between the alumni current position and the gained knowledge. The methodology in this study was a survey. Data were collected by sending mailed questionnaires to all graduates of the Faculty of Nursing University of Indonesia throughout the country. The data was analyzed electrically by SSP program. Univariate statistical tests were employed to analyze the data. Four hundred sixty one mailed questionnaires were sent to alumni of Program A \& B, and 200 questionnaires were returned (43\%). The findings indicated that the graduates of the Faculty of Nursing of University of Indonesia who spread out in 18 provinces in Indonesia have been working in the field of education (70\%) and the majority position as faculty members (52\%). The waiting period to get the first job for those who were graduated from Program A (61\%) was less than 1 month. Through this study, the Faculty of Nursing UI. The inputs identified the methods of learning process which were assumed as very encouraging ways for successful teaching learning processes. There were clinical practice $(23,5 \%)$ and group discussion $(19,2)$, mean while the courses which were significantly needed to be improved were Leadership \& Management in Nursing and Nursing Research. 
Key Words: Education System, Learning Methods 